\title{
Promotion of Tumorigenesis and Clinical Implications of Viral Infection in Breast Cancer
}

Afsar Rahbar

Department of Medicine, Centre for Molecular Medicine, Karolinska Institute, S-171 76 Stockholm, Sweden

*Corresponding author: Afsar Rahbar, PhD, Senior Researcher, Experimental Medicine Research Unit, Department of Medicine, Centre for Molecular Medicine, Karolinska Institute, S-171 76 Stockholm, Sweden; Tel: +46-8-51779897; E-mail: afsar.rahbar@ki.se

Received date: January 06, 2015; Accepted date: March 16 2014; Published date: March 24, 2014

Copyright: ( 2015 Rahbar A. This is an open-access article distributed under the terms of the Creative Commons Attribution License, which permits unrestricted use, distribution, and reproduction in any medium, provided the original author and source are credited.

\begin{abstract}
The prevalence of breast cancer is rising worldwide. The main cause of death from breast cancer is distant metastasis, which occurs within 3 years after diagnosis in $10-15 \%$ of patients. The initiation and progression of breast cancer have been related to both external and internal factors, including viral infection. Human cytomegalovirus infection (HCMV) is common in breast cancer and metastases, and high tumor levels of HCMV appear to worsen outcomes. HCMV can increase the malignant behavior of tumor cells by modulating multiple cellular regulatory and signaling pathways and enhance the proliferation, survival, invasion, motility, and adhesion of tumor cells. Although HCMV seems to have an oncomodulatory role in breast cancer, definitive evidence for a causal role is lacking, and further studies are needed. The current review will discuss evidence that links viral infections to breast cancer.
\end{abstract}

Keywords: Breast cancer; MMTV; HCMV; EBV; HPV; Polyomaviruses

\section{Abbreviations:}

HCMV: Human Cytomegalovirus; MMTV: Mouse Mammary Tumor Virus; HPV: Human Papilloma Virus; EBV: Epstein-Barr Virus

\section{Breast Cancer}

Breast cancer has been mentioned in almost every period of documented history, beginning with the Egyptians, who described the disease some 3500 years ago [1-4]. The discovery of X-rays in 1895 gave physicians a tool for detecting breast tumors, identifying tumor borders, defining tumor spread, and localizing breast tumors for pathological analysis [5,6]. In 1985, a randomized trial of 134,867 women aged 40-74 showed that mammography reduced mortality from breast cancer by $31 \%$ [7].

The number of breast cancer cases is increasing worldwide. Reports from Cancer Research UK showed that breast cancer was diagnosed in 49,900 women in 2011 , a $72 \%$ increase since the mid-1970s [8]. In 2011, over 508,000 women in the world died from breast cancer [9]. In the same year, the World Health Organization reported differences in the incidence of breast cancer worldwide, from 89.7 per 100,000 women in Western Europe to 19.3 per 100,000 women in Eastern Africa [9]. The Swedish Social Board reported that breast cancer was the most common cancer in women, responsible for $30.3 \%$ of cases, and that the average annual increase was $1.3 \%$ over the preceding two decades [10]. In the US, during 2007-2011, the prevalence of breast cancer was as high as 124.6 per 100,000 per year and the number of yearly deaths was 22.2 per 100,000 [11]. Latest world breast cancer statistics from 2012, present increased breast cancer incidence by more than $20 \%$ since 2008 , while mortality is increased by $14 \%$ and breast cancer represents one in four of all cancers in women [12].
The prognosis for breast cancer patients has improved tremendously in the past two decades. Recent studies demonstrate a 5year overall survival rate of $90 \%$, and a decline in mortality between 1975 and 2006 [13].

Several risk factors have been associated to development of breast cancer including weight, diet, exercise, alcohol consumption, smoking, exposure to estrogen, recent oral contraceptive use, stress and anxiety, gender (being a woman is the most significant risk factor for developing breast cancer), high age, never breastfed a child, family history of breast cancer, radiation therapy to the chest, hyperplasia in breast cells in breast biopsy, Lobular carcinoma in situ, mammographically dense breasts, personal history of endometrium, ovary, or colon cancer and exposure to estrogen (in environment for instance in meat) [14].

Despite advances in therapy, however, metastatic breast cancer remains incurable, with a 5-year survival rate of only $23 \%$ [15]. Treatment options are lacking, largely because the biological processes underlying tumor progression and metastasis are not fully understood.

The origin of breast cancers has been suggested to be ductal or lobular. Ductal carcinoma is the most common type; especially at later stages, symptoms become visible with the formation of lumps. Breast cancers are divided into three subtypes: about $60 \%$ are estrogen- or progesterone-positive (ER/PR), 20\% have increased expression of the oncogene human epidermal growth factor receptor 2 (HER-2/neu), and $20 \%$ are triple-negative, lacking expression of ER, PR, and Her-2/neu [16-19].

The development of breast cancer has been linked to several internal and external risk factors. The internal factors include inherited mutations and epigenetic alterations in the BRCA1/BRCA2 genes [20], a family history of breast cancer, ethnicity, dense breast tissue, lifestyle, hormonal contraception, and obesity [21]. Notable external factors include infections [22] and viruses. One virus in particular has received increasing attention: we and others have found 
Page 2 of 7

that human cytomegalovirus (HCMV) infection is highly prevalent in breast cancer tissues and in lymph nodes and brain metastases from breast cancer patients [23-25]. Moreover, outcomes appear to be worse in patients with high levels of HCMV in their tumors or metastases. Despite the possible role of this virus in the initiation and progression of breast cancer, definitive evidence for a causal role is lacking.

\section{Viral Infections Possibly Linked to Breast Cancer}

\section{Promotion of tumorigenesis by Mouse mammary tumor virus (MMTV) in breast cancer}

MMTV is a milk-transmitted retrovirus that leads to mammary tumors in adult mice [26]. MMTV was linked to human breast cancer approximately 50 years ago [26]. In 1971, B particles resembling MMTV were found in milk from a majority of breast cancer patients $[27,28]$. MMTV transcripts were identified in breast cancer samples in some studies but not in others [28,29]. In 1989, the discovery that insertion of the MMTV pro-viral genome activated pro-oncogenes was awarded the Nobel prize [30]. Several animal studies have shown that MMTV, acting as an insertional mutagen, activates and cooperates with three families of proto-oncogenes: Wnt genes, FGF genes, and Notch-related genes [31-33]. Other studies have shown tumor development in MMTV-cyclin D1 transgenic mice, which emphasizes the importance of cyclin D1 in breast cancer [34,35]. Alterations in expression of these genes can cause unlimited cell growth and migration, which can lead to tumor development [36].

Current evidence suggests that, in breast cancer specimens, MMTV infection is present at low levels, and the viral genome can be detected only by PCR, casting doubt on the link between MMTV and breast cancer [28]. In addition, MMTV has not been shown to integrate into human DNA and trigger an oncogenic pathway leading to breast cancer in humans [28]. Thus, the Hill and Koch criteria for a causative role of MMTV in breast cancer have not been met. Isolation of MMTV from breast cancer specimens would also be required to show that MMTV has a role in the disease [28].

\section{Promotion of tumorigenesis by Polyomaviruses in breast cancer}

Polyomaviruses such as SV40, JCV, BK, and Merkel cell polyomavirus are small non-enveloped DNA viruses that have been associated with several forms of cancer [37]. JCV-T-antigen binds to and affects the function of p53 and beta-catenin and causes G2 cell arrest by activating G2-mediated pathways [38].

The notion that SV40 is involved in breast cancer and other human malignancies arose in the 1950s [39], when it was discovered that an SV40-contaminated vaccine had been used for mass immunizations for polio [39]. Thorough epidemiological studies concluded that vaccine recipients did not have a higher incidence of cancer, suggesting that SV40 is not a clinically relevant human oncovirus. However, in an animal model, expression of SV40 large T-antigen altered gene expression in mammary epithelia cells by binding to $\mathrm{Rb}$ proteins, which led to cell immortalization, pre-neoplastic lesions, and invasive metastatic cancer $[38,40,41]$.

In a study of human BK and JCV in breast carcinoma, $23 \%$ of tumor specimens were positive for JCV virus, but none were positive for $\mathrm{BK}$ virus, and neither virus was found in adjacent nontumor tissue [42]. In other studies, JCV was not detected in breast cancer tissues, and MCV was found in only $2 \%[43,44]$. Thus, the role of polyomaviruses in breast cancer is still controversial and under investigation.

\section{Promotion of tumorigenesis by Human papilloma virus (HPV) in breast cancer}

HPV, a small DNA virus that infects skin, mucosal membranes, and keratinocytes, is highly associated with cervical cancer. HPV-16 and 18 are thought to cause $70 \%$ of all cervical cancers [45]. The viral sequences are integrated into the host cellular DNA [45] and can significantly enhance the activity of c-Myc, which is also overexpressed in breast cancer and other malignancies [45]. The HPV early genes E6 and E7 encode proteins that confer oncogenic functions [46]. They can inactivate p53 and pRB [47] and enhance telomerase activity and cause immortalization of infected cells [48]. HPV has been detected in breast cancer after menarche, and also been during pregnancy and lactation, which confirms that latent virus can be re-activated by sex hormones [49]. In vitro, HPV infection can immortalize mammary epithelial cells [50]. However, the presence of HPV in breast cancer is controversial [51,52].

\section{Promotion of tumorigenesis by Human Epstein-Barr virus (EBV) in breast cancer}

EBV, a ubiquitous DNA virus of the Herpesviridae family, infects more than $90 \%$ of world's population $[53,54]$. The infection is usually asymptomatic in children, but may cause severe mononucleosis, prolonged fever, and malaise in teenagers and adults. EBV infects and replicates in B-cells and establishes life-long persistence in the B-cell pool [54]. During latency, at least $8 \mathrm{EBV}$-encoded nuclear or membrane proteins and several small noncoding viral RNAs including EBNA-1 and EBNA-2 are expressed [53,54]. Latent virus can be reactivated periodically, especially in carriers who are immunosuppressed [53,54].

Several malignant diseases have been associated with EBV in immunocompromised patients, including endemic Burkitt lymphoma, T-cell lymphoma, nasopharyngeal carcinoma, Hodgkin's lymphoma, and immunoblastic lymphoma [55]. In these patients, EBV antibody levels are usually elevated, and EBV nucleic acids and latency proteins have been detected in clinical samples [55]. Despite its high prevalence, EBV is believed to cause malignancy only in a small subset of individuals, perhaps because the virus acts in concert with genetic aberrations or mutations or with other infections and environmental factors. Gruhne et al. showed that three EBV latency proteins (EBV nuclear antigens 1 and $3 \mathrm{C}$ and latent membrane protein 1) independently promote genomic instability, which is a hallmark of cancer and is associated with chromosomal aberrations and deregulation of tumor suppressor genes [56-58]. Furthermore, EBV latency proteins restore tumorigenicity, suppress apoptosis by targeting expression of c-MYC and by elevated levels of Bcl-2 [59].

EBV has also been associated with gastric carcinoma, breast cancer, and other epithelial malignancies. However, evidence for the association with breast cancer is conflicting. In some studies, EBVDNA and proteins were found in $50 \%$ of breast cancer specimens and $12 \%$ of adjacent nontumor breast tissues; in other studies, however, the virus was undetectable in breast tumors [60-62]. 


\section{Promotion of tumorigenesis by Human Cytomegalovirus (HCMV) in breast cancer}

HCMV is a DNA virus of the Herpesviridae family. The prevalence of HCMV ranges from $60-80 \%$ in developed countries to approximately $100 \%$ in developing countries [63]. After a primary infection, HCMV establish latency in a small percentage of peripheral blood monocytes [64] and in CD34+ myeloid progenitor cells in bone marrow [65]. The virus can be reactivated by inflammation and immune activation and may lead to severe disease in immunosuppressed patients [66,67]. However, transcripts associated with HCMV latency (e.g., UL81-82, UL138 open reading frame, UL111a, and US28) and expression of immunogenic proteins (e.g., latency unique natural antigen) have been reported during latency and may stimulate the immune system $[68,69]$.

HCMV causes morbidity and mortality in AIDS patients, transplant recipients, and other immunocompromised individuals [70]. Primary HCMV infection in pregnant women is rare but results in congenital infection in about two thirds of cases. Such infections can seriously damage the central nervous system (CNS), leading to mental retardation, hearing loss, and visual impairment [71]. In about $90 \%$ of HCMV-seropositive mothers, reactivated HCMV in breast milk can cause subclinical infections in infants; as a result, HCMV is found in $30-40 \%$ of 1-year-old children [72]. These observations reveal an additional site of persistent HCMV infection that may have implications for breast cancer development.

HCMV infection contributes to the pathogenesis of chronic inflammatory conditions such as inflammatory bowel diseases [73], cardiovascular diseases [74], transplant vascular sclerosis (TVS) in solid organ transplant recipients [75], systemic lupus erythematosus [76], and rheumatoid arthritis [77]. In fact, the inflammatory milieu is an excellent environment for reactivation of latent HCMV. Reactivated HCMV can then boost inflammation by inducing expression of COX-2 and 5-lipoxygenase and by enhancing the production of inflammatory factors such as leukotriens, prostaglandins, interleukin (IL)-1, IL-6, IL-8, IL-10, RANTES, monocyte chemoattractant protein 1 , and macrophage inflammatory protein 1 . In chronic inflammatory diseases, the constant release of inflammatory cytokines may result in migration of more latently infected peripheral blood monocytes to inflamed tissues, which can differentiate into macrophages (MQ)/dendritic cells (DCs) and reactivation of latent virus. HCMV infection can then spread to nearby cells of various types, including vessel endothelial, smooth muscle, epithelial, glial, stromal, and neuronal cells, fibroblasts, and hepatocytes and may exacerbate malignant disease by enhancing the production of inflammatory factors.

Chronic inflammation has long been associated with cancer and is now an established hallmark [78], along with genetic modifications, self-sufficient and uncontrolled cellular growth, activated oncogenes, dysfunctional tumor suppressors, lack of response to anti-proliferative signals, and evasion of apoptosis, all of which contribute fundamentally to oncogenesis $[79,80]$. Pathogens may cause chronic infection or irritation that furthers cancer development through the production of free radicals, which can lead to oxidative damage, nitration of DNA bases, and increased risk of DNA mutations [81].

HCMV infection has been linked to breast cancer in several studies over the last decade. Studies that relied on HCMV serology showed increased levels of $\operatorname{IgG}$ antibodies against HCMV in breast cancer patients $[82,83]$. In particular, the higher prevalence of HCMV in young women with inflammatory breast cancer [84] supports the hypothesis HCMV infection contributes to breast cancer. We and others have shown a very high prevalence of HCMV proteins and nucleic acids in tumor tissues and in lymph node and brain metastases of women with breast cancer [23-25]. More than $90 \%$ of primary tumors, $94 \%$ of lymph node metastases, and $98 \%$ of brain metastases of breast cancer are HCMV positive. Interestingly the infection is largely restricted to tumor cells, although some endothelial cells and inflammatory cells may also be positive. The reason why early studies failed to detect HCMV in breast cancer tissues might be the lack of the advanced laboratory techniques available today to diagnose HCMV infection in tumor specimens.

Although HCMV is highly prevalent in certain tumor tissues, its potential causative role in tumor development is poorly understood. Since HCMV cannot cause malignant transformation of cells, it is not considered to be oncogenic. During evolution HCMV has co-exist in human and has developed mechanisms to avoid viral elimination by the immune system, establishes latency and adapted to persist in the immunocompetent host. HCMV infection may protect tumor cells from apoptosis by expression of HCMV-IE anti-apoptotic proteins IE1, IE2, UL36, UL37, and UL38 to avoid immune clearance by NK and cytotoxic T cells. HCMV anti-apoptotic proteins inhibit apoptosis by upregulating Bcl-2-like activity and blocking the cleavage of procaspase-8, which may results in resistant to chemotherapeutic agents [85]. Notably, previous studies have reported increased expression of Bcl-2 in HCMV infected neuroblastoma and colon carcinoma cell lines with significantly less sensitivity to cytotoxic agents, which was restored by ganciclovir treatment and lowering Bc1-2 levels in these cells [85]. HCMV-UL36 expression in tumor cells may contribute to tumorigenesis of the cells by expression of a viral cell-death suppressor (vICA) $[86,87]$. In addition, HCMV infection in tumor cells may enhance tumorgenecity of these cells by increasing AKt activity (cellular protein kinase B) via activation of P13-K pathway and alteration in cellular metabolism and inhibition of apoptosis [88]. HCMV-IE2 mediates apoptotic control in HCMV retinitis by upregulating the expression of cellular FLICE-inhibitory protein [89-91]. Baillie et al have previously shown an anti-apoptotic effect of HCMV in Glioblastoma cells by induced reduction in TNF receptor-1 expression and consecutively inhibition of TNF-alpha signaling [89]. Moreover, expression of HCMV-US2 and US11 gene products in tumor cells may protect these cells from immune recognition and NK cell-mediated killing by down regulating expression of HLA-I and HLA-II [92].

Nevertheless, the virus has oncomodulatory effects on tumor cells that may lead to a more aggressive phenotype and a poor response to chemotherapy and immunotherapy. Thus, like oncogenic DNA viruses such as HPV and adenovirus, HCMV can increase the malignancy of tumor cells by modulating regulatory and signaling pathways to enhance their proliferation, survival, invasion, motility, and adhesion and by providing sophisticated strategies to avoid immune recognition and killing of infected cells [90]. For example, HCMV proteins can influence cell cycle progression by interacting with regulatory proteins. HCMV infection induces cell cycle arrest by inhibiting cyclin-A expression, resulting in inhibition of cellular DNA synthesis and enhance cell cycle progression by increasing cyclin-E and it is associated kinase activity (CDK2), which is required for G1/S transition [91]. Cyclin E/CDK2 phosphorylates a tumor suppressor protein "Retinoblastoma protein $(\mathrm{Rb})$ " and release E2F transcription factor and drive cells to S-phase [92] In addition, the HCMV immediate early protein (IE) 72, IE86, and tegument protein pp71 
bind to members of retinoblastoma family $(\mathrm{Rb})$ in the cells and activate the transcription factor E2F and induce expression of S-phase genes [90]. Previous studies have shown a correlation between overexpression of cyclin $\mathrm{E}$ with tumorigenesis in certain tumors including breast cancer [93] Moreover, in infected cells, HCMV proteins IE86 and UL111A (which encodes morphological transforming region II) and UL44 can interact with and inhibit the function of p53 and control p21 degradation, resulting in increased expression of cyclins, which are essential for DNA replication during the G1 phase [94,95]. In addition, HCMV-IE 72 and 86 proteins disrupt cell cycle and induce oncogenic transformation in combination with Adenovirus E1A oncogenic proteins [96] HCMV also enhances the transcriptional activity of fos, jun, myc, and other oncogenes [97]. Furthermore, HCMV infection can drive neoplastic transformation in vulnerable adult stem cells by causing chromosomal damage in positions 1q42 and 1q21 $[98,99]$. Interestingly, the possible targets near $1 \mathrm{q} 42$ and 1q21 are potential tumor suppressor genes, whose deletion has been linked to gliomas and primary breast cancer, respectively $[100,101]$.

HCMV-UL76 protein can induce DNA damage, apoptosis, cell cycle arrest [102] and inhibition of DNA repair machinery [103]. Previous studies have shown expression of HCMV-UL76 is not restricted to lytic replication and HCMV-UL76 can be detected in latently infected hematopoietic CD34+ cells and stable expression of HCMV-UL76 in glioblastoma cells inhibits viral replication in these cells $[104,105]$. Persistent expression of HCMV-UL76 in the cells and inhibition of viral replication leads to accumulation of multiple chromosome aberrations, chromosome misalignments, and increased formation of micronuclei containing activated DNA damage signal $\gamma$ H2AX [102].

US28, a G protein-coupled receptor encoded by HCMV, affects the Wnt signaling pathway by activating beta catenin and induces oncogenesis in vivo [106]. Activated beta catenin is frequently detected in invasive breast cancer and has a high impact on worsens patient outcome [107]. In addition, Maussang et al. has previously shown cell cycle progression and cyclin D1 expression by US28 in cells with neoplastic phenotype [108]. Previously, we showed that HCMV IE72 stimulates telomerase activity, which further supports the oncomodulatory activity of this virus [109-111].

In breast cancer patients, we found a high prevalence of HCMV infection in lymph node and brain metastases $[23,24]$. The main cause of death in these women is metastases to distant organs, which occurs within 3 years after diagnosis in about $10-15 \%$ of patients [112]. HCMV infection may influence breast cancer metastasis by different means, possibly by increasing expression of factors important in inflammation and angiogenesis and by inducing epithelial-tomesenchymal transition [113]. HCMV infection enhances the production of potential inflammatory factors, including prostaglandin E2 and leukotriene B4, by inducing expression of COX-2 and 5lipoxygenase, respectively. These inflammatory factors are also involved in cellular proliferation and migration, angiogenesis, and metastasis formation and are targets for nonsteroidal antiinflammatory drugs (NSAIDs) [106,114,115]. Interestingly, NSAIDs also have anti-HCMV activity [116]. Epidemiological studies support the hypothesis that inflammation is a factor in tumor development. Long-term use of NSAIDs is strongly associated with a decreased incidence of breast cancer and other malignancies [117], perhaps through a mechanism involving HCMV's effects on COX expression.

Vascular endothelial growth factor (VEGF), which is important in vascular permeability and tumor angiogenesis, is highly expressed in breast cancer metastases $[118,119]$. Of note, HCMV increases VEGF production. This effect is mediated by US28, an HCMV-encoded chemokine receptor homologue [120] that may be oncomodulatory or even oncogenic [106,114]. US28 protein expression enhances angiogenesis and cellular proliferation by increasing the release of IL-6 and VEGF and the phosphorylation of STAT-3 [106,114]. Furthermore, HCMV-UL146 and UL-147 encodes for viral homolog of CXCL1 (growth related oncogene; Gro-alpha) a potent chemokine with significant role in angiogenesis and may contribute to tumor angiogenesis [88]. In addition, HCMV infection may further contribute to tumor genesis and tumor growth by impairing production of TSP-1 and TSP-2 in HCMV infected cells. Increased vascular count density and high grade of glioblastoma has been associated with lack of TSP-2 [88]. Glioblastoma tumors reported to be frequently HCMV positive [121-127].

In addition, interaction between HCMV and PDGF-R alpha leads to STAT3 hyperactivation and enhanced cellular proliferation [128].

Moreover, HCMV infection induces CD40 on the surface of the infected cells that interact with CD40L and results in VEGF production [129]. Moreover, increased expression of integrin av $\beta 3$, CXCR4/SDF-1, and CD44 may promote angiogenesis and initiate metastasis formation [130-132]. High expression of HCMV US27, another putative chemokine receptor, has been associated with enhanced expression of CXCR4 and induces cellular migration [133]. In addition, HCMV infection increase expression of CD44, which increases cell-cell interactions, cell adhesion, and migration of infected cells [134].

Emerging evidence suggests that HCMV protein and nucleic acids are common in other malignancies, including glioblastoma (GBM), neuroblastoma, medulloblastoma, and rhabdomyosrcoma. Interestingly, clinical studies from our hospital showed that GBM patients benefit from long-term treatment with the anti-HCMV drug valganciclovir (Valcyte) as an add-on to standard therapy $[135,136]$. The 2-year survival rate was higher in treated patients than in contemporary controls ( $62 \%$ vs. $18 \%$ ) of similar age, disease stage, surgical resection grade, and baseline treatment [135,136]. It is not known whether this well-tolerated treatment could reduce morbidity and mortality among women with breast cancer, and especially their risk of developing metastatic breast cancer.

In conclusion, HCMV appears to be highly prevalent in primary and metastatic breast cancer. Further biological studies are needed to assess the role of HCMV in the pathogenesis and progression of the disease. Clinical trials should be considered to evaluate the efficacy of antiviral therapy targeting HCMV as add-on to standard therapies for breast cancer, especially in patients at high risk of metastatic disease.

\section{References}

1. http://assets.cambridge.org/97805214/96322/excerpt/ 9780521496322_excerpt.pdf.

2. http://www.cancer.org/cancer/cancerbasics/thehistoryofcancer/index.

3. http://www.cancerresearchuk.org.

4. http://www.randomhistory.com/1-50/029cancer.html.

5. Gillam LH, Hewitt JK, Warne GL (2010) Ethical principles for the management of infants with disorders of sex development.Horm Res Paediatr 74: 412-418.

6. Shapiro S, Strax P (2005) Evaluation of periodic breast cancer screening with mammography. Methodology and early observations in Classic papers in modern diagnostic radiology. 
7. Tabar L, Fagerberg CJ, Gad A, Baldetorp L, Holmberg LH, et al. (1985) Reduction in mortality from breast cancer after mass screening with mammography. Randomised trial from the Breast Cancer Screening Working Group of the Swedish National Board of Health and Welfare. Lancet 1: 829-32.

8. http://www.cancer.org/acs/groups/cid/documents/webcontent/002048pdf.pdf.

9. http://www.who.int/cancer/detection/breastcancer/en/index1.html.

10. http://www.socialstyrelsen.se/lists/artikelkatalog/attachments/ 18919/2012-12-19.pdf.

11. http://seer.cancer.gov/statfacts/html/breast.html.

12. http://www.iarc.fr/en/media-centre/pr/2013/pdfs/pr223_E.pdf.

13. Siegel R, Ward E, Brawley O, Jemal A (2011) Cancer statistics, 2011: the impact of eliminating socioeconomic and racial disparities on premature cancer deaths.CA Cancer J Clin 61: 212-236.

14. http://www.breastcancer.org/symptoms/understand_bc/risk/factors

15. http://www.cancer.org/acs/groups/content/@epidemiologysurveilance/ documents/document/acspc-030975.pdf.

16. Buzdar AU (2009) Role of biologic therapy and chemotherapy in hormone receptor- and HER2-positive breast cancer.Ann Oncol 20 993-999.

17. Slamon DJ, Leyland-Jones B, Shak S, Fuchs H, Paton V, et al. (2001) Use of chemotherapy plus a monoclonal antibody against HER2 for metastatic breast cancer that overexpresses HER2.N Engl J Med 344 783-792.

18. Anders CK, Carey LA (2009) Biology, metastatic patterns, and treatment of patients with triple-negative breast cancer.Clin Breast Cancer 9 Suppl 2: S73-81.

19. Buzdar AU (2009) Role of biologic therapy and chemotherapy in hormone receptor- and HER2-positive breast cancer.Ann Oncol 20: 993-999.

20. Zhong Q, Peng HL, Zhao X, Zhang L, Hwang WT (2014) Effects of BRCA1- and BRCA2-related mutations on ovarian and breast cancer survival: A meta-analysis. Clinical cancer research : an official journal of the American Association for Cancer Research OCT 27.

21. Li X (2008) Tes, a potential Mena-related cancer therapy target.Drug Discov Ther 2: 1 .

22. Parkin DM (2006) The global health burden of infection-associated cancers in the year 2002.Int J Cancer 118: 3030-3044.

23. Taher C, Frisk G, Fuentes S, Religa P, Costa H, et al. (2014) High prevalence of human cytomegalovirus in brain metastases of patients with primary breast and colorectal cancers. Transl Oncol 7: 732-740.

24. Taher C, de Boniface J, Mohammad AA, Religa P, Hartman J, et al. (2013) High prevalence of human cytomegalovirus proteins and nucleic acids in primary breast cancer and metastatic sentinel lymph nodes.PLoS One 8: e56795.

25. Harkins LE, Matlaf LA, Soroceanu L, Klemm K, Britt WJ, et al. (2010) Detection of human cytomegalovirus in normal and neoplastic breast epithelium.Herpesviridae 1: 8.

26. Bittner JJ (1936) SOME POSSIBLE EFFECTS OF NURSING ON THE MAMMARY GLAND TUMOR INCIDENCE IN MICE.Science 84: 162.

27. Moore DH, Charney J, Kramarsky B, Lasfargues EY, Sarkar NH, et al. (1971) Search for a human breast cancer virus.Nature 229: 611-614.

28. Mason AL, Gilady SY, Mackey JR (2011) Mouse mammary tumor virus in human breast cancer red herring or smoking gun? Am J Pathol 179: 1588-1590.

29. Mant C, Cason J (2004) A human murine mammary tumour virus-like agent is an unconvincing aetiological agent for human breast cancer.Rev Med Virol 14: 169-177.

30. http://www.nobelprize.org/nobel_prizes/medicine/laureates/1989/ press.html.

31. Theodorou V, Kimm MA, Boer M, Wessels L, Theelen W, et al. (2007) MMTV insertional mutagenesis identifies genes, gene families and pathways involved in mammary cancer.Nat Genet 39: 759-769.
32. Grimm SL, Nordeen SK (1998) Mouse mammary tumor virus sequences responsible for activating cellular oncogenes.J Virol 72: 9428-9435.

33. van Leeuwen F, Nusse R (1995) Oncogene activation and oncogene cooperation in MMTV-induced mouse mammary cancer.Semin Cancer Biol 6: 127-133.

34. Pirkmaier A, Dow R, Ganiatsas S, Waring P, Warren K, et al. (2003) Alternative mammary oncogenic pathways are induced by D-type cyclins; MMTV-cyclin D3 transgenic mice develop squamous cell carcinoma.Oncogene 22: 4425-4433.

35. Wang TC, Cardiff RD, Zukerberg L, Lees E, Arnold A, et al. (1994) Mammary hyperplasia and carcinoma in MMTV-cyclin D1 transgenic mice.Nature 369: 669-671.

36. Nusse R, Varmus H (2012) Three decades of Wnts: a personal perspective on how a scientific field developed.EMBO J 31: 2670-2684.

37. Ahsan N, Shah KV (2006) Polyomaviruses and human diseases.Adv Exp Med Biol 577: 1-18.

38. Alibek K, Kakpenova A2, Mussabekova A2, Sypabekova M2, Karatayeva N2 (2013) Role of viruses in the development of breast cancer.Infect Agent Cancer 8: 32.

39. Carbone M, Pass HI, Miele L, Bocchetta M (2003) New developments about the association of SV40 with human mesothelioma.Oncogene 22: 5173-5180.

40. Hoenerhoff MJ, Shibata MA, Bode A, Green JE (2011) Pathologic progression of mammary carcinomas in a C3(1)/SV40 T/t-antigen transgenic rat model of human triple-negative and Her2-positive breast cancer.Transgenic Res 20: 247-259.

41. Marcotte R, Muller WJ (2008) Signal transduction in transgenic mouse models of human breast cancer--implications for human breast cancer.J Mammary Gland Biol Neoplasia 13: 323-335.

42. Hachana M, Amara K, Ziadi S, Gacem RB, Korbi S, et al. (2012) Investigation of human JC and $\mathrm{BK}$ polyomaviruses in breast carcinomas.Breast Cancer Res Treat 133: 969-977.

43. Antonsson A, Bialasiewicz S, Rockett RJ, Jacob K, Bennett IC, et al. (2012) Exploring the prevalence of ten polyomaviruses and two herpes viruses in breast cancer.PLoS One 7: e39842.

44. Hachana M, Amara K, Ziadi S, Gacem RB, Korbi S, et al. (2012) Investigation of human JC and $\mathrm{BK}$ polyomaviruses in breast carcinomas.Breast Cancer Res Treat 133: 969-977.

45. McMurray HR, McCance DJ (2003) Human papillomavirus type 16 E6 activates TERT gene transcription through induction of c-Myc and release of USF-mediated repression.J Virol 77: 9852-9861.

46. Münger K, Scheffner M, Huibregtse JM, Howley PM (1992) Interactions of HPV E6 and E7 oncoproteins with tumour suppressor gene products.Cancer Surv 12: 197-217.

47. Wang T, Chang P, Wang L, Yao Q, Guo W, et al. (2012) The role of human papillomavirus infection in breast cancer.Med Oncol 29: 48-55.

48. Fan X, Liu Y, Chen JJ (2003) Activation of c-Myc contributes to bovine papillomavirus type 1 E7-induced cell proliferation.J Biol Chem 278: 43163-43168.

49. Aceto GM, Solano AR, Neuman MI, Veschi S, Morgano A, et al. (2010) High-risk human papilloma virus infection, tumor pathophenotypes, and BRCA1/2 and TP53 status in juvenile breast cancer. Breast Cancer Res Treat 122: 671-83.

50. Dimri G, Band H, Band V (2005) Mammary epithelial cell transformation: insights from cell culture and mouse models.Breast Cancer Res 7: 171-179.

51. Simões PW, Medeiros LR, Simões Pires PD, Edelweiss MI, Rosa DD, et al. (2012) Prevalence of human papillomavirus in breast cancer: a systematic review.Int J Gynecol Cancer 22: 343-347.

52. Holland JF, Pogo BG (2012) Comment on the review by Joshi and Buehring.Breast Cancer Res Treat 136: 303-307.

53. Young LS, Rickinson AB (2004) Epstein-Barr virus: 40 years on.Nat Rev Cancer 4: 757-768.

54. Chen MR (2011) Epstein-barr virus, the immune system, and associated diseases.Front Microbiol 2: 5. 
55. Brady G, Macarthur GJ, Farrell PJ (2008) Epstein-Barr virus and Burkitt lymphoma.Postgrad Med J 84: 372-377.

56. Gruhne B, Sompallae R, Masucci MG (2009) Three Epstein-Barr virus latency proteins independently promote genomic instability by inducing DNA damage, inhibiting DNA repair and inactivating cell cycle checkpoints. . Oncogene 28: 3999-4008.

57. Stollmann B, Fonatsch C, Havers W (1985) Persistent Epstein-Barr virus infection associated with monosomy 7 or chromosome 3 abnormality in childhood myeloproliferative disorders.Br J Haematol 60: 183-196.

58. Raptis S, Bapat B (2006) Genetic instability in human tumors.EXS : 303-320.

59. Milner AE, Grand RJ, Waters CM, Gregory CD (1993) Apoptosis in Burkitt lymphoma cells is driven by c-myc.Oncogene 8: 3385-3391.

60. Khan G, Philip PS, Al Ashari M (2011) Is Epstein-Barr virus associated with aggressive forms of breast cancer?Br J Cancer 104: 1362-1363.

61. Mazouni C, Fina F, Romain S, Ouafik L, Bonnier P, et al. (2011) EpsteinBarr virus as a marker of biological aggressiveness in breast cancer.Br J Cancer 104: 332-337.

62. He JR, Tang LY, Yu DD, Su FX, Song EW, et al. (2011) Epstein-Barr virus and breast cancer: serological study in a high-incidence area of nasopharyngeal carcinoma.Cancer Lett 309: 128-136.

63. Griffiths PD, Grundy JE (1987) Molecular biology and immunology of cytomegalovirus.Biochem J 241: 313-324.

64. Taylor-Wiedeman J, Sissons JG, Borysiewicz LK, Sinclair JH (1991) Monocytes are a major site of persistence of human cytomegalovirus in peripheral blood mononuclear cells.J Gen Virol 72 : 2059-2064.

65. Mendelson M, Monard S, Sissons P, Sinclair J (1996) Detection of endogenous human cytomegalovirus in $\mathrm{CD} 34+$ bone marrow progenitors.J Gen Virol 77 : 3099-3102.

66. Söderberg-Nauclér C, Fish KN, Nelson JA (1997) Reactivation of latent human cytomegalovirus by allogeneic stimulation of blood cells from healthy donors. Cell 91: 119-126.

67. Reeves MB, MacAry PA, Lehner PJ, Sissons JG, Sinclair JH (2005) Latency, chromatin remodeling, and reactivation of human cytomegalovirus in the dendritic cells of healthy carriers. Proc Natl Acad Sci U S A 102: 4140-4145.

68. Kondo K, Xu J, Mocarski ES (1996) Human cytomegalovirus latent gene expression in granulocyte-macrophage progenitors in culture and in seropositive individuals.Proc Natl Acad Sci U S A 93: 11137-11142.

69. Keyes LR, Hargett D, Soland M, Bego MG, Rossetto CC, et al. (2012) HCMV protein LUNA is required for viral reactivation from latently infected primary CD14ầ cells.PLoS One 7: e52827.

70. Emery VC (2001) Investigation of CMV disease in immunocompromised patients.J Clin Pathol 54: 84-88.

71. Gaytant MA, Steegers EA, Semmekrot BA, Merkus HM, Galama JM (2002) Congenital cytomegalovirus infection: review of the epidemiology and outcome.Obstet Gynecol Surv 57: 245-256.

72. Townsend CL, Forsgren M, Ahlfors K, Ivarsson SA, Tookey PA, et al. (2013) Long-term outcomes of congenital cytomegalovirus infection in Sweden and the United Kingdom. Clin Infect Dis 56: 1232-1239.

73. Rahbar A, Bostrom L, Lagerstedt U, Magnusson I, Söderberg-Naucler C, et al. (2003) Evidence of active cytomegalovirus infection and increased production of IL-6 in tissue specimens obtained from patients with inflammatory bowel diseases. Inflamm Bowel Dis 9: 154-161.

74. Yaiw KC, Ovchinnikova O, Taher C, Mohammad AA, Davoudi B, et al. (2013) High prevalence of human cytomegalovirus in carotid atherosclerotic plaques obtained from Russian patients undergoing carotid endarterectomy. Herpesviridae 4: 3.

75. Hryniewiecka E, Sołdacki D, Pączek L (2014) Cytomegaloviral infection in solid organ transplant recipients: preliminary report of one transplant center experience. Transplant Proc 46: 2572-2575.

76. Sekigawa I, Nawata M, Seta N, Yamada M, Iida N, et al. (2002) Cytomegalovirus infection in patients with systemic lupus erythematosus.Clin Exp Rheumatol 20: 559-564.
77. Fasth AE, Snir O, Johansson AA, Nordmark B, Rahbar A, et al. (2007) Skewed distribution of proinflammatory $\mathrm{CD} 4+\mathrm{CD} 28$ null $\mathrm{T}$ cells in rheumatoid arthritis.Arthritis Res Ther 9: R87.

78. Hanahan D, Weinberg RA (2011) Hallmarks of cancer: the next generation.Cell 144: 646-674.

79. Hanahan D, Weinberg RA (2000) The hallmarks of cancer.Cell 100: 57-70.

80. Rakoff-Nahoum S (2006) Why cancer and inflammation? Yale J Biol Med 79: $123-130$

81. Hussain PS, Harris CC (2008) Inflammation and human cancer. Pathogenesis and Clinical Practice in Gastroenterology 160: 137-146.

82. Cox B, Richardson A, Graham P, Gislefoss RE, Jellum E, et al. (2010) Breast cancer, cytomegalovirus and Epstein-Barr virus: a nested casecontrol study.Br J Cancer 102: 1665-1669.

83. Richardson A (1997) Is breast cancer caused by late exposure to a common virus?Med Hypotheses 48: 491-497.

84. El-Shinawi M, Mohamed HT, El-Ghonaimy EA, Tantawy M, Younis A, et al. (2013) Human cytomegalovirus infection enhances NF- $\hat{I}^{\circ} \mathrm{B} / \mathrm{p} 65$ signaling in inflammatory breast cancer patients.PLoS One 8: e55755.

85. Cinatl J Jr, Cinatl J, Vogel JU, Kotchetkov R, Driever PH, et al. (1998) Persistent human cytomegalovirus infection induces drug resistance and alteration of programmed cell death in human neuroblastoma cells.Cancer Res 58: 367-372.

86. Cinatl J, Scholz M, Kotchetkov R, Vogel JU, Doerr HW (2004) Molecular mechanisms of the modulatory effects of HCMV infection in tumor cell biology.Trends Mol Med 10: 19-23.

87. Vossen MT, Westerhout EM, Söderberg-Nauclér C, Wiertz EJ (2002) Viral immune evasion: a masterpiece of evolution.Immunogenetics 54: 527-542.

88. Cinatl J Jr, Vogel JU, Kotchetkov R, Wilhelm Doerr H (2004) Oncomodulatory signals by regulatory proteins encoded by human cytomegalovirus: a novel role for viral infection in tumor progression. FEMS Microbiol Rev 28: 59-77.

89. Baillie J, Sahlender DA, Sinclair JH (2003) Human cytomegalovirus infection inhibits tumor necrosis factor alpha (TNF-alpha) signaling by targeting the 55-kilodalton TNF-alpha receptor.J Virol 77: 7007-7016.

90. Cinatl J Jr, Vogel JU, Kotchetkov R, Wilhelm Doerr H (2004) Oncomodulatory signals by regulatory proteins encoded by human cytomegalovirus: a novel role for viral infection in tumor progression.FEMS Microbiol Rev 28: 59-77.

91. Salvant BS, Fortunato EA, Spector DH (1998) Cell cycle dysregulation by human cytomegalovirus: influence of the cell cycle phase at the time of infection and effects on cyclin transcription.J Virol 72: 3729-3741.

92. Hinds PW, Mittnacht S, Dulic V, Arnold A, Reed SI, et al. (1992) Regulation of retinoblastoma protein functions by ectopic expression of human cyclins.Cell 70: 993-1006.

93. Donnellan R, Chetty R (1999) Cyclin E in human cancers.FASEB J 13: 773-780.

94. Bresnahan WA, Albrecht T, Thompson EA (1998) The cyclin E promoter is activated by human cytomegalovirus $86-\mathrm{kDa}$ immediate early protein.J Biol Chem 273: 22075-22082.

95. Wade M, Kowalik TF, Mudryj M, Huang ES, Azizkhan JC (1992) E2F mediates dihydrofolate reductase promoter activation and multiprotein complex formation in human cytomegalovirus infection. Mol Cell Biol 12: 4364-4374.

96. Shen Y, Zhu H, Shenk T (1997) Human cytomagalovirus IE1 and IE2 proteins are mutagenic and mediate "hit-and-run" oncogenic transformation in cooperation with the adenovirus E1A proteins. Proc Natl Acad Sci U S A 94: 3341-3345.

97. Boldogh I, AbuBakar S, Deng CZ, Albrecht T (1991) Transcriptional activation of cellular oncogenes fos, jun, and myc by human cytomegalovirus.J Virol 65: 1568-1571.

98. Vishnu P, Aboulafia DM (2013) The Oncogenicity of Human Cytomegalovirus. In N. M. a. S. Patricia Price ed Manifestations of Cytomegalovirus Infection. InTech. 
99. Fortunato EA, Dell'Aquila ML, Spector DH (2000) Specific chromosome 1 breaks induced by human cytomegalovirus.Proc Natl Acad Sci U S A 97: 853-858.

100. Champeme M, Mazoyer S, Stoppalyonnet D, Bieche I, Ithier G, et al. (1995) Sublocalization of smallest common regions of deletion on chromosome 17q12-q23 in sporadic primary breast-tumors.Oncol Rep 2: 825-831.

101. Baumgartner M, Schneider R, Auer B, Herzog H, Schweiger M, et al. (1992) Fluorescence in situ mapping of the human nuclear NAD+ ADPribosyltransferase gene (ADPRT) and two secondary sites to human chromosomal bands 1q42, 13q34, and 14q24.Cytogenet Cell Genet 61: 172-174.

102. Siew VK, Duh CY, Wang SK (2009) Human cytomegalovirus UL76 induces chromosome aberrations.J Biomed Sci 16: 107.

103. Xiaofei E, Kowalik TF (2014) The DNA damage response induced by infection with human cytomegalovirus and other viruses.Viruses 6: 2155-2185.

104. Goodrum F, Jordan CT, Terhune SS, High K, Shenk T (2004) Differential outcomes of human cytomegalovirus infection in primitive hematopoietic cell subpopulations.Blood 104: 687-695.

105. Goodrum FD, Jordan CT, High K, Shenk T (2002) Human cytomegalovirus gene expression during infection of primary hematopoietic progenitor cells: A model for latency. Proceedings of the National Academy of Sciences of the United States of America 99: $16255-16260$.

106. Bongers G, Maussang D, Muniz LR, Noriega VM, Fraile-Ramos A, et al. (2010) The cytomegalovirus-encoded chemokine receptor US28 promotes intestinal neoplasia in transgenic mice.J Clin Invest 120: 3969-3978.

107. Lin SY, Xia W, Wang JC, Kwong KY, Spohn B, et al. (2000) Beta-catenin, a novel prognostic marker for breast cancer: its roles in cyclin D1 expression and cancer progression.Proc Natl Acad Sci U S A 97: 4262-4266.

108. Maussang D, Verzijl D, van Walsum M, Leurs R, Holl J, et al. (2006) Human cytomegalovirus-encoded chemokine receptor US28 promotes tumorigenesis.Proc Natl Acad Sci U S A 103: 13068-13073.

109. Strååt K, Liu C, Rahbar A, Zhu Q, Liu L, et al. (2009) Activation of telomerase by human cytomegalovirus.J Natl Cancer Inst 101: 488-497.

110. Zhu H, Shen Y, Shenk T (1995) Human cytomegalovirus IE1 and IE2 proteins block apoptosis.J Virol 69: 7960-7970.

111. Terhune S, Torigoi E, Moorman N, Silva M, Qian Z, et al. (2007) Human cytomegalovirus UL38 protein blocks apoptosis.J Virol 81: 3109-3123.

112. Weigelt B, Peterse JL, van't Veer LJ (2005) Breast cancer metastasis: markers and models. Nat Rev Cancer 5: 591-602.

113. Shimamura M, Murphy-Ullich JE, Britt WJ (2010) Human cytomegalovirus induces TGF- $\hat{I}^{2} 1$ activation in renal tubular epithelial cells after epithelial-to-mesenchymal transition.PLoS Pathog 6: e1001170.

114. Slinger E, Maussang D, Schreiber A, Siderius M, Rahbar A, et al. (2010) HCMV-encoded chemokine receptor US28 mediates proliferative signaling through the IL-6-STAT3 axis.Sci Signal 3: ra58.

115. Wang D, Dubois RN (2006) Prostaglandins and cancer. Gut 55: 115-122.

116. Schröer J, Shenk $T$ (2008) Inhibition of cyclooxygenase activity blocks cell-to-cell spread of human cytomegalovirus.Proc Natl Acad Sci U S A 105: 19468-19473.

117. Burn J, Gerdes AM, Macrae F, Mecklin JP, Moeslein G, et al. (2011) Long-term effect of aspirin on cancer risk in carriers of hereditary colorectal cancer: an analysis from the CAPP2 randomised controlled trial. The Lancet 378: 2081-2087.

118. Kurebayashi J, Otsuki T, Kunisue H, Mikami Y, Tanaka K, et al. (1999) Expression of vascular endothelial growth factor (VEGF) family members in breast cancer.Jpn J Cancer Res 90: 977-981.
119. Goel HL, Mercurio AM (2013) VEGF targets the tumour cell.Nat Rev Cancer 13: 871-882.

120. Reinhardt B, Schaarschmidt P, Bossert A, Lüske A, Finkenzeller G, et al. (2005) Upregulation of functionally active vascular endothelial growth factor by human cytomegalovirus. J Gen Virol 86: 23-30.

121. Rahbar A, Stragliotto G, Orrego A, Peredo I, Taher C, et al. (2012) Low levels of Human Cytomegalovirus Infection in Glioblastoma multiforme associates with patient survival; -a case-control study.Herpesviridae 3:3.

122. Rahbar A, Orrego A, Peredo I, Dzabic M, Wolmer-Solberg N, et al. (2013) Human cytomegalovirus infection levels in glioblastoma multiforme are of prognostic value for survival. J Clin Virol 57: 36-42.

123. Mitchell DA, Xie W, Schmittling R, Learn C, Friedman A, et al. (2008) Sensitive detection of human cytomegalovirus in tumors and peripheral blood of patients diagnosed with glioblastoma.Neuro Oncol 10: 10-18.

124. Soroceanu L, Matlaf L, Bezrookove V, Harkins L, Martinez R, et al. (2011) Human cytomegalovirus US28 found in glioblastoma promotes an invasive and angiogenic phenotype.Cancer Res 71: 6643-6653.

125. Ranganathan P, Clark PA, Kuo JS, Salamat MS, Kalejta RF (2012) Significant association of multiple human cytomegalovirus genomic Loci with glioblastoma multiforme samples.J Virol 86: 854-864.

126. Matlaf LA, Harkins LE, Bezrookove V, Cobbs CS, Soroceanu L (2013) Cytomegalovirus pp71 protein is expressed in human glioblastoma and promotes pro-angiogenic signaling by activation of stem cell factor.PLoS One 8: e68176.

127. Cobbs CS, Harkins L, Samanta M, Gillespie GY, Bharara S, et al. (2002) Human cytomegalovirus infection and expression in human malignant glioma.Cancer Res 62: 3347-3350.

128. Hollon TC, Price RL, Kwon CH, Chiocca EA (2013) Mutations in glioblastoma oncosuppressive pathways pave the way for oncomodulatory activity of cytomegalovirus.Oncoimmunology 2 : e25620.

129. Maisch T, Kropff B, Sinzger C, Mach M (2002) Upregulation of CD40 expression on endothelial cells infected with human cytomegalovirus.J Virol 76: 12803-12812.

130. Bos PD, Zhang XH, Nadal C, Shu W, Gomis RR, et al. (2009) Genes that mediate breast cancer metastasis to the brain.Nature 459: 1005-1009.

131. Lorger M, Krueger JS, O'Neal M, Staflin K, Felding-Habermann B (2009) Activation of tumor cell integrin alphavbeta3 controls angiogenesis and metastatic growth in the brain.Proc Natl Acad Sci USA 106: 10666-10671.

132. Lee BC, Lee TH, Avraham S, Avraham HK (2004) Involvement of the chemokine receptor CXCR4 and its ligand stromal cell-derived factor lalpha in breast cancer cell migration through human brain microvascular endothelial cells. Mol Cancer Res 2: 327-338.

133. Arnolds KL, Lares AP, Spencer JV (2013) The US27 gene product of human cytomegalovirus enhances signaling of host chemokine receptor CXCR4.Virology 439: 122-131.

134. Ito M, Watanabe M, Ihara T, Kamiya H, Sakurai M (1995) Increased expression of adhesion molecules (CD54, CD29 and CD44) on fibroblasts infected with cytomegalovirus.Microbiol Immunol 39: 129-133.

135. Stragliotto G, Rahbar A, Solberg NW, Lilja A, Taher C, et al. (2013) Effects of valganciclovir as an add-on therapy in patients with cytomegalovirus-positive glioblastoma: a randomized, double-blind, hypothesis-generating study. Int J Cancer 133: 1204-1213.

136. Söderberg-Nauclér C, Rahbar A, Stragliotto G (2013) Survival in patients with glioblastoma receiving valganciclovir.N Engl J Med 369: 985-986. 